\title{
APPLICATION OF COMMERCIAL AIRCRAFT SELECTION IN AVIATION INDUSTRY THROUGH MULTI-CRITERIA DECISION MAKING METHODS
}

\author{
Kasım KİRACI1 \\ Mahmut BAKIR ${ }^{2}$
}

\begin{abstract}
The purpose of this study is to determine the most suitable aircraft type by ranking the most demanded aircrafts by airline companies according to several criteria. In this context, the most ordered aircraft types in 2016; A320, A321, B737-800 and B737900ER were analyzed based on their cost, performance and environmental factors. AHP, COPRAS and MOORA methods were used in the study. The findings of the study show that the results of multicriteria decision making methods are consistent with each other and that the most appropriate type of aircraft is Boeing 737-800.
\end{abstract}

Selection

Keywords: MCDM Methods, AHP, COPRAS, MOORA, Aircraft

\section{ÇOK KRITTERLİ KARAR VERME YÖNTEMLERI İLE HAVACILIK SEKTÖRÜNDE TICARİ UÇAK SEÇIMİ UYGULAMASI ÖZ}

$\mathrm{Bu}$ çalışmanın amacl, havayolu şirketleri tarafından en çok talep edilen hava araçlarını bir takım kriterlere göre sıralayıp en uygun hava aracının belirlenmesidir. Bu kapsamda, 2016 yll itibariyle havayolu firmaları tarafından en fazla sipariș edilen A320, A321, B737-800 ve B737-900ER uçak tipleri, maliyet, performans ve çevre faktörleri dikkate alınarak analiz edilmiştir. Çalışmada AHP, COPRAS ve MOORA yöntemleri kullanılmıştır. Çalışmanın bulguları, çok kriterli karar verme yöntemlerinin birbirleri ile tutarlı sonuçlar verdiğini ve en uygun hava aracı tipinin Boeing 737-800 olduğunu göstermektedir.

Anahtar Kelimeler: ÇKKV Yöntemleri, AHP, COPRAS, MOORA, Uçak Seçimi

\section{Introduction}

Companies in the aviation sector are seen to pursue a number of strategies in order to gain competitive advantage. Relying on these strategies and considering the market factors, airlines conduct their operations more efficiently and effectively. One of the most important strategic decisions of airlines is to have a sustainable fleet structure. In this regard, airlines tend to prefer aircrafts that fit into their

\footnotetext{
1 İskenderun Teknik Üniversitesi, Havacılık Yönetimi Bölümü, kasim.kiraci@iste.edu.tr

${ }^{2}$ Anadolu Üniversitesi, Havacılık Yönetimi Bölümü, mahmutbakir@anadolu.edu.tr
} 
business model, passenger profile and flight range. Therefore, aircraft selection is one of the basic policies that airlines must implement in order to perform profitable operations and gain competitive advantage.

The main aim of this study is to use different decision-making methods to determine the most suitable aircraft for the airlines. Several studies exist in the literature on aircraft selection. Some of the conducted studies are seen to have focused on case studies by creating different scenarios (Teoh and Khoo, 2015; Dožić and Kalić, 2015; Listes and Dekker, 2005). The focal point of these studies was to determine the most suitable aircraft or fleet structure for the airline under different scenarios. In addition to this, some studies focus on determining the most suitable aircrafts for particular airlines (Ozdemir and Basligil, 2016) as well as empirically examining the determinants of aircraft selection for many flight points (Givoni and Rietveld, 2010).

This study aims to determine the most suitable aircraft selection for airline companies. The study seeks to provide complementary knowledge to the work previously conducted on the selection of aircraft. In this context, unlike previous studies, the performances of the most demanded aircrafts by airline companies have been examined in this study. Another contribution of the study to the literature is that three different multi-criteria decision making methods are used integrally to analyze the performance of the aircrafts. The results are intended to determine both the best performing aircraft as well as the presence or otherwise, of consistency between the methods. Finally, the study presents an original structure in terms of the evaluation criteria used. An examination of comparison criteria employed indicates that cost, performance and environmental factors are all taken into consideration. These evaluation criteria are of great importance for both the airlines and the air transport sector stakeholders.

\section{Literature Review}

Many studies in the extant literature have discussed the selection of ideal aircraft or fleet based on different criteria and using different methods. The studies focused mostly on the determination of the aircraft or fleet structure that will ensure the best performance to airlines. In selecting the best performing aircrafts, consideration of aircraft usage areas is crucial in determining the selection criteria and selecting the aircraft to be included in the sampling. For instance, 
Wang and Chang (2007) conducted a study on determining the most suitable initial training aircraft. In the study, they included small training propeller aircrafts in the sample and ranked them according to the selected criteria. There are also studies in the literature that aim to determine the most appropriate aircraft or fleet structure based on the flight routes of airlines. Harasani (2006) investigated the most suitable aircraft fleet for an airline based in Jeddah. Dožić and Kalić (2013) examined the most appropriate aircraft choice for flights from Belgrade Airport. Similarly, Dožić and Kalić (2014) researched on the most suitable aircraft for an airline operating in Southeast Europe with 27 flight points. Ozdemir et al. (2011) examined mid-range aircrafts based on key criteria such as cost, time and physical characteristics.

The identification of suitable aircrafts and establishing suitable fleet structures based on flight range is fundamental to airlines. The choice of suitable aircrafts sets the stage for airlines to operate more efficiently and effectively thereby attaining competitive advantage. On the other hand, when determining "the most suitable aircraft", which aircrafts are used and which selection criteria are preferred can significantly affect the comparison results. Although there are no accepted selection parameters in the literature, the capacity, speed and cost of the aircraft are among the most important determinants. On examination of extant literature, studies are found to compare different aircrafts based on different parameters and then determining the best performing aircraft based on this comparison. Further studies in the literature are represented in the table below (Table 1). 
Table 1: Summary of studies on aircraft type selection nexus

\begin{tabular}{|c|c|c|c|}
\hline Authors & Methodology & Criteria & Comparison/Output \\
\hline $\begin{array}{l}\text { See and Lewis } \\
\text { (2002) }\end{array}$ & Multi-attribute method & Speed, Max. Range, Number of passengers & $\begin{array}{c}\text { Comparison of } 4 \text { aircraft types } \\
\text { (demonstrate the strengths and } \\
\text { weaknesses of the various decision- } \\
\text { making approaches) }\end{array}$ \\
\hline $\begin{array}{c}\text { Listes and } \\
\text { Dekker (2005) }\end{array}$ & $\begin{array}{l}\text { Scenario aggregation } \\
\text { based approach }\end{array}$ & $\begin{array}{l}\text { Load factor, Spill, Revenues, Operating } \\
\text { costs, Fleet cost, Profit }\end{array}$ & Comparison of 9 aircraft types \\
\hline $\begin{array}{l}\text { Wang and Chang } \\
\text { (2007) }\end{array}$ & fuzzy TOPSIS method & A/c performance parameters (16 Criteria) & $\begin{array}{c}\text { Comparison of } 7 \text { aircraft types } \\
\text { (evaluating initial training aircraft) }\end{array}$ \\
\hline $\begin{array}{l}\text { Yeh and Chang } \\
\text { (2009) }\end{array}$ & $\begin{array}{c}\text { New Fuzzy } \\
\text { multicriteria decision } \\
\text { making (MCDM) } \\
\text { approach }\end{array}$ & $\begin{array}{l}\text { Technological advance, Social } \\
\text { responsibility, Economical efficiency (11 } \\
\text { Criteria) }\end{array}$ & Comparison of 5 aircraft types \\
\hline
\end{tabular}

310 | Manisa Celal Bayar Üniversitesi Sosyal Bilimler Dergisi - Cilt: 16, Sayı: 4, Aralık 2018 


\begin{tabular}{cccc}
\hline $\begin{array}{c}\text { Gomes et al., } \\
(2014)\end{array}$ & NAIADE Method & Financial, Logistics, Quality (11 Criteria) & Comparison of 8 aircraft types \\
\hline Harasani (2013) & $\begin{array}{c}\text { Roskam (1990) five- } \\
\text { step approach }\end{array}$ & $\begin{array}{c}\text { Daily pax per route, a/c performance } \\
\text { parameters, cost efficiency }\end{array}$ & $\begin{array}{c}\text { Comparison of 6 aircraft types for } \\
\text { airline located in Madinah }\end{array}$ \\
\hline $\begin{array}{c}\text { Dožić and Kalić } \\
(2013)\end{array}$ & Even Swaps Method & $\begin{array}{c}\text { Seat capacity, Price, Payment conditions, } \\
\text { Total baggage, MTOW, Baggage per } \\
\text { passenger }\end{array}$ & Comparison of 7 aircraft types \\
\hline $\begin{array}{c}\text { Dožić and Kalić } \\
(2014)\end{array}$ & $\begin{array}{c}\text { Analytic Hierarchy } \\
\text { Process (AHP) }\end{array}$ & $\begin{array}{c}\text { Price of aircraft, payment conditions, } \\
\text { CASM, seat capacity, total baggage, MTOM }\end{array}$ & Comparison of 7 aircraft types \\
\hline $\begin{array}{c}\text { Teoh and Khoo } \\
(2015)\end{array}$ & $\begin{array}{c}\text { Analytic Hierarchy } \\
\text { Process (AHP) }\end{array}$ & $\begin{array}{c}\text { Load factor, Passengers carried, RPK, ASK, } \\
\text { Fuel Efficiency }\end{array}$ & $\begin{array}{c}\text { Comparison of 3 aircraft types for } \\
\text { airline fleet planning decision- } \\
\text { making }\end{array}$ \\
\hline $\begin{array}{c}\text { Dožić and Kalić } \\
(2015)\end{array}$ & $\begin{array}{c}\text { Fuzzy logic and Even } \\
\text { Swaps Method }\end{array}$ & $\begin{array}{c}\text { Air travel demand/distance, Seat capacity, } \\
\text { Price of aircraft, Luggage per passenger, } \\
\text { MTOM, Unit trip costs }\end{array}$ & $\begin{array}{c}\text { Fleet structure, fleet size, the most } \\
\text { appropriate aircraft }\end{array}$ \\
\hline $\begin{array}{c}\text { Bruno et al., } \\
(2015)\end{array}$ & AHP and Fuzzy Set \\
Theory & $\begin{array}{c}\text { Economic performance, Technical } \\
\text { performance, Aircraft interior quality, } \\
\text { Environmental impact (8 Criteria) }\end{array}$ & Comparison of 3 aircraft types \\
\hline $\begin{array}{c}\text { Ozdemir and } \\
\text { Basligil (2016) }\end{array}$ & fuzzy AHP and fuzzy \\
ANP & $\begin{array}{c}\text { Cost, Time, Physical Attributes and Others } \\
\text { (10 Criteria) }\end{array}$ & Comparison of 3 aircraft types \\
\hline
\end{tabular}




\section{Methodology}

\subsection{Analytic Hierarchy Process (AHP)}

The Analytical Hierarchy Process is one of the most used multicriteria decision-making (MCDM) methods in complex decision problems that involve selecting the best alternatives by determining the criterion weights of the pairwise comparison of criteria and alternatives (Hu and Jian-liang, 2008; Sarıçalı and Kundakçı, 2016). The main objective of the AHP is to achieve at the best solution in multi-criteria decision making problems by considering the purpose, the criteria, sub-criteria and the alternatives (Ömürbek and Şimşek, 2012).

The most important features of the AHP are its ability to allowing the decision maker to make both subjective and objective evaluations (Kuruüzüm and Atsan, 2001) and the ability to present the problem in detail with the hierarchical structure (Sarıçalı and Kundakçı, 2016). AHP derives its powers from its ability to handle factors that prove difficult or impossible for many other approaches, but which also affect decisions (Özdemir, 2002).

The steps for application of the AHP can be formulated as follows (Ömürbek and Şimşek, 2012; Çelik and Ustasüleyman, 2014; Zhao et al., 2009):

\section{Problem}

Step 1: Establishing the Model and Formulating the

In the application of AHP, all qualitative and quantitative variables affecting the decision process must first be determined in line with the literature, surveys or expert views. Next, the acquired information is used to form a hierarchical structure based on the purpose, criteria, sub-criteria and alternatives. However, care should be taken to ensure that the selected criteria are clear and understandable.

\section{Step 2: Constructing a Pairwise Comparison Matrix}

Following the creation of the hierarchical structure, the relative importance degrees of the governing criteria are calculated. At this point, a pairwise comparison matrix is obtained by comparing the decision criteria and the alternatives under the criteria. The binary comparison matrix is shown in Table 2:

Table 2: Construction of a pairwise comparison matrix 


\begin{tabular}{|l|l|l|l|l|}
\hline & Criteria 1 & Criteria 2 & $\ldots$ & Criteria n \\
\hline Criteria 1 & $\mathrm{W}_{1} / \mathrm{W}_{1}$ & $\mathrm{~W}_{1} / \mathrm{W}_{2}$ & $\ldots$ & $\mathrm{W}_{1} / \mathrm{W}_{\mathrm{n}}$ \\
\hline Criteria 2 & $\mathrm{W}_{2} / \mathrm{W}_{1}$ & $\mathrm{~W}_{2} / \mathrm{W}_{2}$ & $\ldots$ & $\mathrm{W}_{2} / \mathrm{W}_{\mathrm{n}}$ \\
\hline$\ldots$ & $\ldots$ & $\ldots$ & $\ldots$ & $\ldots$ \\
\hline Criteria $\mathrm{n}$ & $\mathrm{W}_{\mathrm{n}} / \mathrm{W}_{1}$ & $\mathrm{~W}_{\mathrm{n}} / \mathrm{W}_{2}$ & $\ldots$ & $\mathrm{W}_{\mathrm{n}} / \mathrm{W}_{\mathrm{n}}$ \\
\hline
\end{tabular}

Source: (Özdemir, 2002)

The terms in the matrix are the result of pairwise comparison of the criteria with each other using the 1-9 scale suggested by T.L Saaty and then the relative importance degree of the criteria is calculated. This comparison scale is shown in Table 3 (Saaty, 2008).

Table 3: Pairwise Comparison Scale

\begin{tabular}{lcc}
\hline $\begin{array}{l}\text { Degree of } \\
\text { Importance }\end{array}$ & Definition & Description \\
\hline 1 & Equal & $\begin{array}{c}\text { The two choices are equally } \\
\text { important. } \\
\text { One choice is comparatively } \\
\text { slightly more important }\end{array}$ \\
5 & Moderate & $\begin{array}{c}\text { One choice is comparatively more } \\
\text { important. }\end{array}$ \\
7 & Strong & $\begin{array}{c}\text { One choice is comparatively much } \\
\text { more important. }\end{array}$ \\
9 & Very Strong & $\begin{array}{c}\text { One choice is absolutely more } \\
\text { important. }\end{array}$ \\
$2,4,6,8$ & Absolute & Intermediate \\
Values & Represents intermediate values. \\
\hline
\end{tabular}

\section{Scores}

Step 3: Determining the Criteria Weights and Alternative

In this step, the weight of each alternative is calculated through pairwise comparisons. To obtain this, each column value in the matrix is divided by the sum of its column and the matrix becomes normalized. The sum of each column in the normalized matrix is 1 (Ömürbek and Şimşek, 2012). Then, the eigenvectors are obtained by taking the average of the values in each row.

\section{Stage 4: Obtaining Consistency Rate}

At this stage of the method, the AHP method will have some inconsistency as it is based on the subjective opinions of the experts, 
so the consistency ratio must be calculated. The consistency index (CI) is calculated using the following notation (Eq. 2):

$$
\mathrm{CI}=\frac{\lambda_{\max }-\mathrm{n}}{\mathrm{n}-1}
$$

In the notation, $\mathrm{CI}$ is the consistency index, $\lambda_{\max }$ is the largest eigenvalue in the matrix and $n$ is the number of elements in each matrix. In order to calculate the consistency ratio, the value of the random index (RI) corresponding to the number of decision alternatives is determined. The RI values are determined from the randomness index shown in Table 4. The consistency ratio (CR) is then obtained by dividing the RI value by the CI value (Eq. 3):

$$
\mathrm{CR}=\frac{\mathrm{CI}}{\mathrm{RI}}
$$

The point to note here is that the consistency ratio (CR) is less than 0.10 . If $\mathrm{CR}>0.10$, then there is inconsistency which means that the comparison matrix should be reviewed to make it more consistent (Dündar and Ecer, 2008; Supçiller and Çapraz, 2011).

Table 4: Random Value Index Table

\begin{tabular}{ccccccccccc}
\hline $\mathrm{n}$ & 1 & 2 & 3 & 4 & 5 & 6 & 7 & 8 & 9 & 10 \\
\hline $\mathrm{RI}$ & 0 & 0 & 0,58 & 0,9 & 1,12 & 1,24 & 1,32 & 1,41 & 1,45 & 1,49 \\
\hline
\end{tabular}

Source: (Özdemir, 2002)

\subsection{COPRAS Method}

The COPRAS (COmplex PRPortional ASsessment) method is used to conduct evaluations by ranking alternatives in terms of the importance of the criteria and benefit ratings (Özdağoğlu, 2013). The COPRAS method is used to evaluate the criterion scores, to maximize the beneficial criteria to a higher level and to minimize the useless (cost) criteria to the lowest level (Podvezko, 2011). The advantages of the COPRAS method can be summarized as follows (Aksoy et al., 2015).

- Compared to other MCDM (Multi-Criteria Decision Making) methods such as AHP and TOPSIS, it requires less computation and takes less time.

- Alternatives or options allow ranking.

- The method allows for the possibility of evaluation of both quantitative and qualitative criteria.

The superiority of COPRAS method over the other MCDM methods is that it provides a degree of benefit for alternatives. Comparisons of alternatives with each other reveal, as a percentage, how well or poorly placed the alternative is (Aksoy et al., 2015). Due 
to its ease of application, the COPRAS method has been used in many areas such as construction, property management and economy.

The COPRAS method consists of a 7-step solution process and is based on the following notations (Özdağoğlu, 2013; Sarıçalı and Kundakçl, 2016; Organ and Katrancl, 2016):

\section{Step 1: Creating the Decision Matrix}

Like the other MCDM methods, the first step of the COPRAS method is the creation of a decision matrix which specifies the criteria and the alternatives for the problem and contains the relevant score. The matrix $\mathrm{D}$, defined as the initial matrix, consists of the values $\mathrm{x}_{\mathrm{ij}}$ and is shown below (Eq. 4).

$$
D=\begin{gathered}
A_{1} \\
A_{2} \\
A_{3} \\
\cdot \\
\cdot \\
A_{m}
\end{gathered}\left[\begin{array}{ccccc}
x_{11} & x_{12} & x_{13} & \cdot & x_{1 n} \\
x_{21} & x_{22} & x_{23} & \cdot & x_{2 n} \\
x_{31} & x_{32} & x_{33} & \cdot & x_{3 n} \\
\cdot & \cdot & \cdot & \cdot & \cdot \\
\cdot & \cdot & \cdot & \cdot & \cdot \\
x_{m 1} & x_{m 2} & x_{m 3} & \cdot & x_{m n}
\end{array}\right]
$$

Variables in the model;

$A_{i}:$ i. alternative $i=1,2, \ldots, m$

$\mathrm{K}_{\mathrm{j}}$ : j. evaluation criteria $\mathrm{j}=1,2, \ldots, \mathrm{n}$

$w_{j}$ : the significance level of the evaluation criteria of $j . j=1,2, \ldots, n$

$\mathrm{x}_{\mathrm{ij}}$ : the value of alternative $\mathrm{i}$. in evaluation criteria $\mathrm{j}$.

\section{Step 2: Obtaining the Normalized Decision Matrix}

The normalization process refers to the transformation of scores into common units against the assumption that the scores for the criteria can come from different scales or units. The following notation is used in the normalization of the decision matrix (Eq. 5).

$$
\mathrm{x}_{\mathrm{ij}}^{*}=\frac{\mathrm{x}_{\mathrm{ij}}}{\sum_{\mathrm{i}=1}^{\mathrm{m}} \mathrm{x}_{\mathrm{ij}}} \quad \forall \mathrm{j}=1,2, \ldots, \mathrm{n}
$$

\section{Step 3: Obtaining The Weighted Normalized Matrix}

In the weighting process, the significance coefficient $\left(w_{j}\right)$ for each criterion is multiplied by the scores of normalized decisions matrix to obtain weighted normalized matrix, containing the $\left(d_{i j}\right)$ elements and denoted by $D^{\prime}$ is obtained. The following notation is used for this operation (Eq. 6).

$$
D^{\prime}=d_{i j}=x_{i j}^{*} \cdot w_{j}
$$

\section{Step 4: Obtaining Beneficial and Non-Beneficial Values}


Beneficial values refer to the higher desired values for the purpose to be achieved in the problem, while non-beneficial values represent the desired values that are lower for the desired purpose. While adding the scores in the beneficial criteria in the weighted normalized matrix gives $\mathrm{S}_{\mathrm{i}}^{+}$value, adding the scores of the cost criteria in the matrix gives $S_{i}^{-}$value (Eq. 7).

$$
\begin{array}{r}
S_{i}^{+}=\sum_{j=1}^{k} d_{i j} \quad j=1,2, \ldots, k \\
S_{i}^{-}=\sum_{j=k+1}^{n} d_{i j} \quad j=k+1, k+2, \ldots, n
\end{array}
$$

Step 5: Obtaining Relative Significance Value $\left(Q_{i}\right)$

The $\left(Q_{i}\right)$ values refer to relative significance for each alternative. The highest relative importance value $\left(Q_{i}\right)$ represents the best alternative. The $\left(Q_{i}\right)$ is calculated by the following notation (Eq. 8).

\section{Value}

$$
\mathrm{Q}_{\mathrm{i}}=\mathrm{S}_{\mathrm{i}}^{+}+\frac{\sum_{\mathrm{i}=1}^{\mathrm{m}} \mathrm{S}_{\mathrm{i}}^{-}}{\mathrm{S}_{\mathrm{i}}^{-} \cdot \sum_{\mathrm{i}=1}^{\mathrm{m}} \frac{1}{\mathrm{~S}_{\mathrm{i}}^{-}}}
$$

Step 6: Calculation of the Highest Relative Significance (Eq. 9).

The highest $\left(Q_{i}\right)$ value is obtained using the following notation

$$
\mathrm{Q}_{\max }=\text { the highest }\left\{\mathrm{Q}_{\mathrm{i}}\right\} \quad \forall \mathrm{i}=1,2, \ldots, \mathrm{m}
$$

\section{Alternatives}

Step 7: Obtaining Performance Index $P_{i}$ Values for the

The performance index, $\mathrm{P}_{\mathrm{i}}$, for each alternative, is calculated as follows (Eq. 10).

$$
\mathrm{P}_{\mathrm{i}}=\frac{\mathrm{Q}_{\mathrm{i}}}{\mathrm{Q}_{\max }} \cdot 100 \%
$$

The highest value of $P_{i}$ obtainable is 100 . This value indicates the best alternative in the criteria. The best alternative is determined by ordering the performance index values for each alternative from the largest to the smallest.

\subsection{MOORA method}

The MOORA method developed by Brauers and Zavadskas in 2006 is based on the process of simultaneous optimization in cases of two or more conflicting attributes subject to certain constraints. The MOORA method, which is one of the multi-criteria decision-making methods based on proportional analysis, has recently become one of the frequently used methods in the literature (Tepe and Görener, 2014; Özdağoğlu, 2014). 
There are various MOORA methods in the literature. These can be listed as MOORA-Ratio Method, MOORA-Reference Point Method, MOORA-Significance Coefficient Approach, MOORA-Full Multiplication Form, and MULTI-MOORA. Some studies, however, emphasize that the MOORA method resulted from two basic methods, namely ratio system approach and reference point approach (Şimşek et al., 2015). This study will apply the significance coefficient approach of the MOORA-Ratio Method which is frequently preferred in the literature and considered to be suitable for the purpose of the study.

The ratio method is defined as the benefits (benefit: represents all alternatives for this purpose) upon which the comparison of all alternatives for the objectives are based.

The MOORA-Ratio method consists of the following three steps (Brauers and Zavadskas, 2006; Özdağoğlu, 2014).

\section{Step 1: Creating the Decision Matrix}

The MOORA method starts with a decision matrix X that shows the performance of different alternatives for various qualities or purposes. The decision matrix in the first step is represented as follows (Eq. 11):

where

$$
\mathrm{X}=\left[\begin{array}{cccc}
\mathrm{x}_{11} & \mathrm{x}_{12} & \cdots & \mathrm{x}_{1 \mathrm{n}} \\
\mathrm{x}_{21} & \mathrm{x}_{22} & \cdots & \mathrm{x}_{2 \mathrm{n}} \\
\vdots & \vdots & \ddots & \vdots \\
\mathrm{x}_{\mathrm{m} 1} & \mathrm{x}_{\mathrm{m} 2} & \cdots & \mathrm{x}_{\mathrm{mn}}
\end{array}\right]
$$

$\mathrm{i}=$ alternative

$\mathrm{j}=$ quality or measure

$\mathrm{m}=$ total numbers of alternatives

$\mathrm{n}=$ total number of quality or measures

$x_{i j}=i$ alternative, shows the measure value according to $j$ measurement.

\section{Step 2: Obtaining the Normalized Decision Matrix}

For the solution of the ratio system approach, it is necessary to calculate the value of $x_{i j}$ in the second step. The $x_{i j}$ value contained here is a unitless number in the range $[0,1]$ which represents the normalized performance of the $i$ alternative with reference to $j$ measure or quality. The value of $\mathrm{x}_{\mathrm{ij}}$ is calculated using the notation shown below (Eq. 12):

$$
x_{i j}^{*}=\frac{x_{i j}}{\sqrt{\sum_{j=1}^{m} x_{i j}^{2}}}
$$

\section{Step 3: Obtaining the $y_{i}^{*}$ Values for the Alternatives}


In the last step of the MOORA-Ratio method, the $\mathbf{y}_{\mathbf{i}}^{*}$ values are calculated. At this stage, the $\mathbf{y}_{\mathbf{i}}^{*}$ values are obtained by subtracting the sum of the expected minimum (cost) criteria from the expected maximum (benefit) criteria. On the other hand, in some cases it is often found that some criteria are considered more important than others. To make these criteria more significant in the process, the normalized values of the criteria can be multiplied by the weight coefficients. This process is specific to the significance coefficient approach and the $\mathbf{y}_{\mathbf{i}}^{*}$ values are calculated with the aid of weighted normalized values (Eq. 13).

$$
\mathrm{y}_{\mathrm{i}}^{*}=\sum_{\mathrm{j}=1}^{\mathrm{g}} \mathrm{w}_{\mathrm{j}} \mathrm{x}_{\mathrm{ij}}^{*}-\sum_{\mathrm{j}=\mathrm{g}+1}^{\mathrm{n}} \mathrm{w}_{\mathrm{j}} \mathrm{x}_{\mathrm{ij}}^{*}
$$

The $\mathrm{j}=1,2,3, \ldots, \mathrm{g}$ in the formula indicates the criteria to be maximized while $\mathrm{j}=\mathrm{g}+1, \mathrm{~g}+2, \ldots, \mathrm{n}$ indicates the criteria to be minimized. $w_{j}$ denotes the significance coefficients for the criteria while $y_{i}^{*}$ shows the normalized values according to all the objectives of the $i$. alternative. The obtained values of $y_{i}^{*}$ are ranked from the largest to the smallest. The $\mathbf{y}_{\mathbf{i}}^{*}$ values may be positive or negative hence the decision alternative with the highest $\mathbf{y}_{\mathbf{i}}^{*}$ value is considered as the most appropriate alternative.

\section{Application of The AHP and COPRAS Methods in Aircraft Selection}

The first step taken in resolving the problem of choosing commercial aircrafts for airlines is to determine the selection criteria and the alternative aircraft types. For this study, a selection criterion as indicated in Table 5 was determined through literature review and the support of eight experts who have academic and/or sectoral experience in the airline industry.

Table 5: Obtained Selection Criteria

\begin{tabular}{|c|c|c|}
\hline$e^{\operatorname{Cod}}$ & Criteria & Unit \\
\hline $\mathbf{R A}$ & Range & Nautical mile \\
\hline PR & Price & Million \$ \\
\hline SP & Speed & Knot \\
\hline SC & Seating capacity & $\begin{array}{l}\text { Number of } \\
\text { passengers }\end{array}$ \\
\hline FC & Fuel consumption & Dollar / Mil \\
\hline MP & Maximum payload & Metric ton \\
\hline
\end{tabular}




\section{GG Amount of greenhouse gas release \\ kilogram}

The range is defined as the distance traveled by the aircraft from the point of departure to the arrival point. Airlines always consider their network structure during the selection of aircrafts and they choose the mileage of the aircraft accordingly. Therefore, the range is very important in that it shows the maximum distance that the airline can effectively service (Gomes et al., 2014; Gürün, 2015; Bruno et al., 2015). Airlines should choose the planes with the most appropriate range based on their flight traffic and flight networks.

One of the basic balance sheet items of airlines is the amount of aircrafts they have purchased or rented. Therefore, the price of an aircraft is one of the most important criteria in determining the purchase decision by airlines (Dožić and Kalić, 2014; Dožić and Kalić, 2015). Fixed assets are seen to hold an important place in the total assets when the balance sheets of airlines are examined. It follows therefore that according to the specified criteria, airlines would tend to go for aircrafts with the least cost. The speed of the aircraft, especially on transoceanic long-haul flights is an important criterion for both the airlines and the passengers. Airlines take into account the speed of the aircraft in order to make more flights, increase flight frequencies and best meet the needs and desires of their customers (Wang and Chang, 2007; See et al., 2004; Bruno et al., 2015).

Another important selection criterion for airlines is the seating capacity of the aircrafts (Dožić and Kalić, 2014; See et al., 2004; Gürün, 2015). Airlines prefer aircraft with larger capacities in order to reduce the unit cost per flight and maximize revenue (ceteris paribus). It is therefore likely that, given two aircrafts with similar cost and technical characteristics, airlines will prefer aircraft with higher seat capacity. The other main cost item of airlines is the fuel cost. According to Vasigh et al. (2012), the share of fuel cost in the total cost is approximately $30 \%$. Consequently, one of the most important criteria that should be taken into consideration in the selection of aircraft is their fuel consumption (Gürün, 2015).

The maximum payload is defined as the sum of the passenger, baggage, cargo and postage loads, which constitute part of the takeoff weight of a plane and which represents revenue or potential revenue to the airline (Wensveen, 2011). A larger maximum payload of aircraft increases the revenues of airlines and creates an advantageous position for airlines. Therefore, airlines also take into consideration 
the maximum payload in the selection of aircraft. Finally, the other criterion to be considered in the selection of aircraft is the emission of greenhouse gases. Today, with global warming and environmental pollution having reached critical proportions, there is a serious increase in the consciousness towards the environment both socially and legally. Considering the fact that the amount of emissions from aircraft engines has increased considerably with increasing traffic, this ratio is said to have increased by $87 \%$ from 1990 s to 2006 (European Commission, 2006) - the sensitivity to this factor has also increased and therefore the amount of emissions can be considered as an important criterion in the selection of aircraft.

Once the selection criteria have been determined, decision alternatives appropriate for short- and medium- haul flights are identified. In determining decision alternatives, the demand for aircraft and the amounts of the orders of aircraft are taken as the basis of the method. Research shows that the most ordered aircrafts in 2016 are A320, A321, B737-8 and B737-900ER aircrafts, which are suitable for short and medium-haul flights. Therefore, comparison of the most demanded aircrafts by cost, performance and environmental factors will benefit to both airlines and stakeholders in the aviation sector. To determine the best aircraft for short and medium haul flights, multicriteria empirical methods AHP, COPRAS and MOORA-Ratio methods were used. The methodology applied in the research is summarized as follows (Figure 1). 


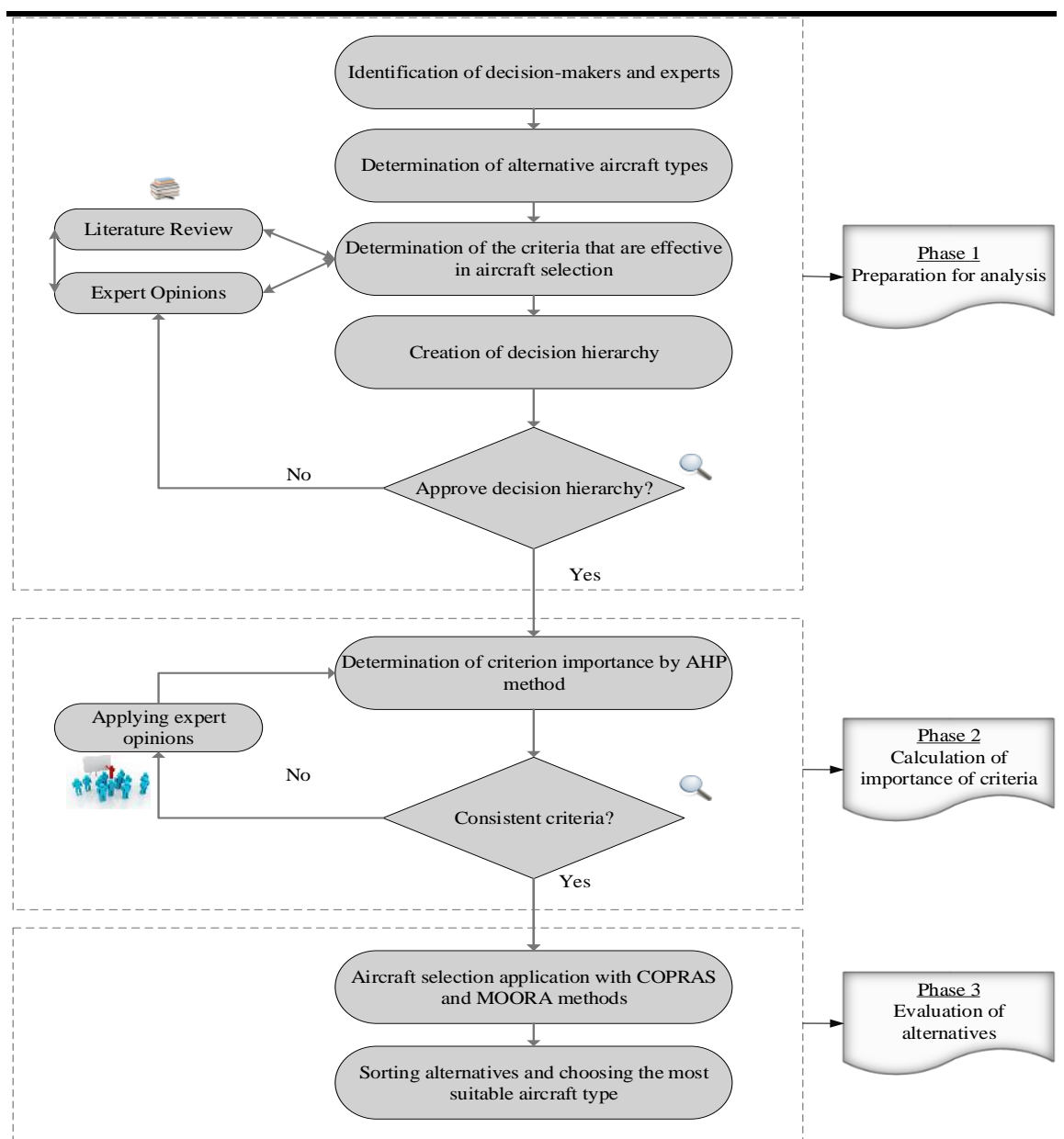

Figure 1: The framework of the proposed methodology used in the study

Resource: Constructed by authors.

\subsection{Application of AHP Method}

In this study, questionnaires which allowed pairwise comparisons, and views from eight experts with academic and/or sectoral experience in the aviation sector were used to determine the criteria and criteria weights used in the selection of commercial aircraft. Fundamental matrices were formed by first establishing a hierarchical structure and then getting the geometric mean of the scores of the criteria (Öztürk and Çekerol, 2015). The initial pairwise 
comparison matrix (1) for the problem of commercial aircraft selection is shown in Table 6 .

Table 6: Pairwise Comparison Matrix of Basic Criteria

\begin{tabular}{|l|c|c|c|c|c|c|c|}
\hline & PR & SP & MP & RA & GG & FC. & SC \\
\hline PR & 1,00 & 4,58 & 1,31 & 1,45 & 5,21 & 1,04 & 1,12 \\
\hline SP & 0,22 & 1,00 & 0,34 & 0,41 & 1,98 & 0,24 & 0,26 \\
\hline MP & 0,76 & 2,94 & 1,00 & 0,72 & 3,56 & 0,44 & 0,37 \\
\hline RA & 0,69 & 2,44 & 1,39 & 1,00 & 3,40 & 0,40 & 0,43 \\
\hline GG & 0,19 & 0,51 & 0,28 & 0,29 & 1,00 & 0,19 & 0,21 \\
\hline FC & 0,96 & 4,17 & 2,27 & 2,5 & 5,26 & 1,00 & 1,53 \\
\hline SC & 0,89 & 3,85 & 2,70 & 2,33 & 0,65 & 0,65 & 1,00 \\
\hline Total & 4,72 & 19,48 & 9,30 & 8,70 & 21,07 & 3,96 & 4,92 \\
\hline
\end{tabular}

In the next step, the normalized matrix is obtained by dividing each alternative score by the column sum. As the normalized matrix is being generated, the criteria weights of the alternatives can also be obtained by getting the averages of the normalized values. The normalized matrix and the criteria weights obtained are given in Table 7.

Table 7: Normalized Decision Matrix and Criteria Weights

\begin{tabular}{|l|c|c|c|c|c|c|c|c|}
\hline & PR & SP & MP & RA & GG & FC. & SC & $\begin{array}{c}\text { Criteria } \\
\text { Weights }\end{array}$ \\
\hline PR & 0,212 & 0,235 & 0,141 & 0,167 & 0,247 & 0,262 & 0,228 & 0,213 \\
\hline SP & 0,046 & 0,051 & 0,037 & 0,047 & 0,094 & 0,061 & 0,053 & 0,056 \\
\hline MP & 0,162 & 0,151 & 0,108 & 0,083 & 0,169 & 0,111 & 0,075 & 0,123 \\
\hline RA & 0,146 & 0,125 & 0,149 & 0,115 & 0,161 & 0,101 & 0,087 & 0,127 \\
\hline GG & 0,041 & 0,026 & 0,030 & 0,034 & 0,047 & 0,048 & 0,043 & 0,038 \\
\hline FC & 0,204 & 0,214 & 0,245 & 0,287 & 0,250 & 0,252 & 0,311 & 0,252 \\
\hline SC & 0,189 & 0,197 & 0,291 & 0,267 & 0,031 & 0,165 & 0,203 & 0,192 \\
\hline \multicolumn{8}{|c|}{$\lambda=7,04224$} & CI=0,00704 RI=1,32 CR=0,0053 \\
(Consistent) \\
\hline
\end{tabular}

In Table 7, the values of the consistency ratio are also calculated using Eq. (2) and (3). Since the consistency ratio (RI) was less than 0.10 , the result was considered to be consistent (Ishizaka and Nemery, 2013).

An examination of Table 7 reveals that according to the decision makers, fuel consumption (0.252) is the most important 
criterion among the 7 criteria evaluated. Fuel consumption is followed by price criterion at a significance coefficient of 0.21 . Greenhouse gas emission, with a significance coefficient of 0.038 is considered to be the least important criterion in the selection of commercial aircraft. It is thus possible to say that experts do not have very high regards for environmental factors in their selection. It is hoped that with the increasing awareness of environmental regulations factors like greenhouse gas emissions will be taken as priorities in making such decisions.

\subsection{Application of COPRAS Method}

After determining the criteria weights that influence the selection of commercial aircrafts using AHP method, we proceeded to rank the alternative airlines using the COPRAS method. Again, the criteria considered included range, price, speed, seating capacity, fuel consumption, maximum payload and greenhouse gas emissions. Alternatives include the A320, A321, B737-800 and B737-900ER models. Since the objective of COPRAS method is to determine the optimum alternative, it is very important to determine the highest (benefit) and lowest (cost) expected criteria. In this study, range, speed, seating capacity and maximum payload were considered as the benefit criteria while price, fuel consumption and greenhouse gas emission were the cost criteria.

\section{Step 1: Creating the Decision Matrix}

Like other MCDM methods, the COPRAS method requires a decision matrix at the beginning. The decision matrix to be used in the COPRAS method is shown in Table 8.

Table 8: Decision Matrix

\begin{tabular}{lccccccc}
\hline & Benefit & Cost & Benefit & Benefit & Cost & Benefit & Cost \\
\cline { 2 - 8 } & RA & PR & SP & SC & FC & MP & GG \\
\hline A320 & 3300 & 98 & 444 & 180 & 13,7 & 16,6 & 2440 \\
A321 & 3200 & 114,9 & 444 & 236 & 14,88 & 21,2 & 3020 \\
B737-800 & 3115 & 79 & 472 & 189 & 13,24 & 20,54 & 2780 \\
B737-900ER & 3200 & 85 & 472 & 215 & 14,69 & 20,24 & 2780 \\
\hline
\end{tabular}

Step 2: Obtaining the Normalized Decision Matrix 
In the COPRAS method, the decision matrix is normalized using Eq. (5). In this step, the normalized values are obtained by dividing each alternative score by column total. The resulting normalized matrix is shown in Table 9.

Table 9: Normalized Matrix

\begin{tabular}{lccccccc}
\hline & RA & PR & SP & SC & FC & MP & GG \\
\hline A320 & 0,257 & 0,260 & 0,242 & 0,219 & 0,242 & 0,211 & 0,22 \\
A321 & 0,249 & 0,304 & 0,242 & 0,287 & 0,263 & 0,269 & 0,27 \\
B737-800 & 0,243 & 0,209 & 0,247 & 0,230 & 0,234 & 0,261 & 0,252 \\
B737-900ER & 0,249 & 0,225 & 0,257 & 0,262 & 0,260 & 0,257 & 0,252 \\
\hline
\end{tabular}

Step 3: Obtaining the Weighted Normalized Matrix

Like the other MCDM methods, the weighted normalized matrix in the COPRAS method is obtained by multiplying the criteria weights representing the significance levels of the alternatives by the scores of the alternatives.

In this step, the weighting process was performed using the criteria weights obtained from the AHP application according to Eq. (6). The decision matrix after the weighting is shown in table 10.

Table 10: Weighted Normalized Matrix

\begin{tabular}{lccccccc}
\hline & $\mathbf{0 . 1 2 7}$ & $\mathbf{0 . 2 1 3}$ & $\mathbf{0 . 0 5 6}$ & $\mathbf{0 . 1 9 2}$ & $\mathbf{0 . 2 5 2}$ & $\mathbf{0 . 1 2 3}$ & $\mathbf{0 . 0 3 8}$ \\
\cline { 2 - 8 } & RA & PR & SP & SC & FC & MP & GG \\
\hline A320 & 0,032 & 0,055 & 0,013 & 0,042 & 0,061 & 0,025 & 0,008 \\
A321 & 0,031 & 0,065 & 0,013 & 0,055 & 0,066 & 0,033 & 0,010 \\
B737-800 & 0,030 & 0,044 & 0,014 & 0,044 & 0,059 & 0,030 & 0,009 \\
B737-900ER & 0,031 & 0,048 & 0,014 & 0,050 & 0,065 & 0,031 & 0,009 \\
\hline
\end{tabular}

Step 4: Obtaining Beneficial and Non-Beneficial Values

At this stage, the values $S_{i}^{+}$and $S_{i}^{-}$for the alternatives are calculated using Eq. (7) and (8). The value $S_{i}^{+}$represents the sum of the weighted normalized values of criteria expected to be high range like speed, seating capacity and maximum payload, while the value $\mathrm{S}_{\mathrm{i}}^{-}$represents the sum of the weighted normalized values of criteria 
expected to be low like price, fuel consumption and greenhouse gas emission. The obtained values are shown in Table 11.

Table 11: $S_{i}^{+}$and $S_{i}^{-}$Values for the Alternatives

\begin{tabular}{lcc}
\hline & \multicolumn{1}{c}{$\mathbf{S}_{\mathbf{i}}^{+}$} & $\mathbf{S}_{\mathbf{i}}^{-}$ \\
\hline $\mathbf{A 3 2 0}$ & 0,114083 & 0,124973 \\
A321 & 0,133386 & 0,141809 \\
B737-800 & 0,121361 & 0,113362 \\
B737-900ER & 0,127820 & 0,123217 \\
\hline
\end{tabular}

Step 5, 6, 7: Obtaining Relative Importance $\left(Q_{i}\right)$ and Performance Index $P_{i}$ Values

At this stage, the relative importance $\left(Q_{i}\right)$ of each alternative is calculated according to Eq. (9). Then performance index $P_{i}$ values for each performance are calculated using Eq. (10). Finally, the $P_{i}$ values obtained are sorted from largest to the smallest. This way, the best alternatives are obtained. The $P_{i}$ and the $\left(Q_{i}\right)$ values of the alternatives and the preferred order of preference of the alternatives are shown in table 12 .

Table 12: The $P_{i}$ and the $\left(Q_{i}\right)$ values of the Alternatives and the Order of the Alternatives

\begin{tabular}{lccc}
\hline & $\mathbf{Q}_{\mathbf{i}}$ & $\mathbf{P}_{\mathbf{i}}$ & Ranking \\
\hline A320 & 0.23999 & 92.246 & 4 \\
A321 & 0.24434 & 93.920 & 3 \\
B737-800 & 0.26016 & 100 & 1 \\
B737-900ER & 0.25552 & 98.216 & 2 \\
\hline
\end{tabular}

As seen in Table 12, according to COPRAS method, and with the criteria determined by airlines, aircraft type "B737-800" with $100 \%$ performance index value is the best alternative. In this case, the worst alternative is " A320 " with a performance index value of $92.246 \%$.

\subsection{Application of MOORA Method}

The third method for aircraft selection problem by airlines is the MOORA method which has applied more frequently in the recent past. Since the same selection criteria and alternative aircraft types 


\section{KasIm KIRACI-Mahmut BAKIR}

were examined in the MOORA method, the related table (Table 7) was not included in order to avoid falling back. For this reason, the second step is applied by the normalization process.

\section{Step 2: Obtaining the Normalized Decision Matrix}

Formation of the decision matrix is the first step of the MOORA method. The next stage entails the normalization of decision matrix using the square root of the sum of the data and the squares of the data. Table 13 shows the cost-benefit information of the data and the normalized values of the data obtained MOORA ratio method operations on the decision matrix. Eq. (12) was used in this process:

Table 13: Normalized Matrix

\begin{tabular}{lccccccc}
\hline & Benefit & Cost & Benefit & Benefit & Cost & Benefit & Cost \\
\hline & RA & PR & SP & SC & FC & MP & GG \\
\hline A320 & 0,5149 & 0,5146 & 0,4845 & 0,4365 & 0,4843 & 0,4208 & 0,4416 \\
A321 & 0,4993 & 0,6033 & 0,4845 & 0,5723 & 0,5260 & 0,5373 & 0,5466 \\
B737-800 & 0,4860 & 0,4148 & 0,5150 & 0,4583 & 0,4680 & 0,5206 & 0,5031 \\
B737-900ER & 0,4993 & 0,4463 & 0,5150 & 0,5214 & 0,5193 & 0,5130 & 0,5031 \\
\hline
\end{tabular}

\section{Step 3: Obtaining the $y_{i}^{*}$ Values for the Alternatives}

To obtain the $\mathrm{y}_{\mathrm{i}}^{*}$ values, it is first necessary to perform the weighting process in accordance with the significance coefficient approach. The weighted normalized matrix is obtained by integrating the significance coefficient approach to the MOORA-Ratio method. To get the weighted normalized values in this step, the matrix in Table 13 is multiplied by the significance coefficients for the criteria obtained from the AHP method. Table 14 shows the weighted matrix obtained using Eq. (13) and the significance coefficients used.

Table 14: Weighted Normalized Matrix

\begin{tabular}{lccccccc}
\hline & $\mathbf{0 . 1 2 7}$ & $\mathbf{0 . 2 1 3}$ & $\mathbf{0 . 0 5 6}$ & $\mathbf{0 . 1 9 2}$ & $\mathbf{0 . 2 5 2}$ & $\mathbf{0 . 1 2 3}$ & $\mathbf{0 . 0 3 8}$ \\
\hline & Benefit & Cost & Benefit & Benefit & Cost & Benefit & Cost \\
\hline RA & PR & SP & SC & FC & MP & GG \\
\hline A320 & 0,0651 & 0,1097 & 0,0269 & 0,0838 & 0,1220 & 0,0516 & 0,0170 \\
A321 & 0,0632 & 0,1286 & 0,0269 & 0,1099 & 0,1325 & 0,0659 & 0,0210 \\
B737-800 & 0,0615 & 0,0884 & 0,0286 & 0,0880 & 0,1179 & 0,0638 & 0,0193 \\
B737-900ER & 0,0632 & 0,0951 & 0,0286 & 0,1001 & 0,1308 & 0,0629 & 0,0193 \\
\hline
\end{tabular}


The last step of the MOORA method is to obtain the $y_{i}^{*}$ score which is the normalized value of the all alternatives. Following the weighting, all decision alternatives are calculated using Eq. $y_{i}^{*}$. The main criteria here is to subtract the sum of the weighted value of the cost criteria from the sum of the weighted values of the benefit criteria. The $y_{i}^{*}$ values of the alternatives and their rankings are shown in Table 15.

Table 15: The $y_{i}^{*}$ Values and the Rankings of the Alternatives

\begin{tabular}{lcc}
\hline & $\mathbf{y}_{\mathbf{i}}^{*}$ & Ranking \\
\hline A320 & -0.021147777 & 4 \\
A321 & -0.016198958 & 3 \\
B737-800 & 0.016330339 & 1 \\
B737-900ER & 0.009558496 & 2 \\
\hline
\end{tabular}

According to the order shown in Table 15 above, type B737800 is the most suitable type of aircraft. Based on the same criteria, the second alternative is B737-900ER and A320 is the most unsuitable alternative.

Finally, the results of the two methods used in ordering the aircraft types of the alternatives are shown in Table 16.

Table 16: Ranking of aircraft types according to MCDM methods

\begin{tabular}{lcc}
\hline & \multicolumn{2}{c}{ Ranking } \\
\cline { 2 - 3 } & COPRAS & MOORA \\
\hline A320 & 4 & 4 \\
A321 & 3 & 3 \\
B737-800 & 1 & 1 \\
B737-900ER & 2 & 2 \\
\hline
\end{tabular}

\section{Conclusion}

Air transport is one of the sectors where competition is intense and where the optimal use of resources is extremely important. Airline companies therefore, have to be very selective about the choice of aircraft which is one of the major cost items. When determining the right aircrafts for their operations, airlines should compare the performance of the aircrafts against a clear set of criteria and choose the aircraft with the best performance. The choice of aircraft is therefore crucial for the efficient use of resources of the airline and 
attaining competitive advantage. In this study, the most demanded short and medium range aircrafts were analyzed using multi-criteria decision-making methods. The criteria used in the aircraft selection process were determined based on a review of the literature and the views of sectoral and academic experts. The AHP method was then used to obtain the criterial weights based on the results of the questionnaires and interviews with the sector experts. To determine the most appropriate aircraft type, COPRAS and MOORA methods were applied on selected decision alternatives in line with the determined criteria.

Four aircrafts with the capability to be used for both short and medium distance flights (A320, A321, B737-800, and B737-900ER) and which were the most ordered in 2016, were selected as decision alternatives for the study. The study sought to determine, according to the determined criteria and through the empirical examination by AHP, COPRAS and MOORA methods, the most suitable aircraft for the airlines. The findings of the study show that the most important criterion in selecting an aircraft is the fuel consumption. This is followed by price, seating capacity, range, maximum payload, speed and the amount of greenhouse gas emissions, respectively. It was also noted that both methods used for ranking showed consistent results. Accordingly, Boeing 737-800 was found to be the most suitable aircraft type among the alternatives. This was followed by Boeing 737900ER and A321 respectively. A320 was determined to be the lowest performing aircraft by both measures. The fact that both empirical methods applied in the study gave the same results with respect to the best and worst performing aircrafts, increases the validity of the study and the reliability of the findings.

\section{KAYNAKLAR}

AKSOY, E., ÖMÜRBEK, N. and KARAATLI, M. (2015) "AHP Temelli MULTIMOORA ve COPRAS yöntemi ile Türkiye Kömür İşletmeleri'nin performans değerlendirmesi" Hacettepe Üniversitesi İktisadi ve İdari Bilimler Fakültesi Dergisi, 33(4): 1-28.

BRAUERS, W. K. and ZAVADSKAS, E. K. (2006) "The MOORA method and its application to privatization in a transition economy" Control and Cybernetics, 35: 445-469.

BRUNO, G., ESPOSITO, E. and GENOVESE, A. (2015) "A model for aircraft evaluation to support strategic decisions" Expert Systems with Applications, 42(13): 5580-5590. 
ÇELİK, P. and USTASÜLEYMAN, T. (2014) "Electre I Ve Promethee Yöntemleri İle GSM Operatörlerinin Hizmet Kalitesinin Değerlendirilmesi" Uluslararası İktisadi ve İdari İncelemeler Dergisi, 6(12): 137-160.

DOŽIĆ, S. and KALIĆ, M. (2013) "Selection of aircraft type by using even swaps method" In 17 th ATRS World Conference, Bergamo, Italy, June: 26-29.

DOŽIĆ, S. and KALIĆ, M. (2014) "An AHP approach to aircraft selection process" Transportation Research Procedia, 3: 165-174.

DOŽIĆ, S. and KALIĆ, M. (2015) "Comparison of two MCDM methodologies in aircraft type selection problem" Transportation Research Procedia, 10: 910-919.

DÜNDAR, S. and ECER, F. (2008) "Öğrencilerin GSM operatörü tercihinin, analitik hiyerarşi süreci yöntemiyle belirlenmesi" Yönetim ve Ekonomi: Celal Bayar Üniversitesi İktisadi ve idari Bilimler Fakültesi Dergisi, 15(1): 195-205.

European Commission. (2006). Climate change: Commission proposes bringing air transport into EU Emissions Trading Scheme, http://europa.eu/rapid/press-release_IP-06-1862_en.htm, (15.09.2017)

GIVONI, M. and RIETVELD, P. (2010) "The environmental implications of airlines' choice of aircraft size" Journal of Air Transport Management, 16(3): 159-167.

GOMES, L. F., MATTOS FERNANDES, J. E. and MELLO, J. C. (2014) "A fuzzy stochastic approach to the multicriteria selection of an aircraft for regional chartering" Journal of Advanced Transportation, 48(3): 223-237.

GÜRÜN, A. (2015) "Sivil Havacılık Sektöründe İş Jeti Seçimi: AHP Yöntemi Uygulaması" Yayınlanmamış Yüksek Lisans Tezi, Eskişehir, Anadolu Üniversitesi Sosyal Bilimler Enstitüsü.

HARASANI, W. I. (2006) "Evaluation and Selection of a Fleet of Aircraft for a Local Airline" Journal of King. Abdulaziz University: Engineering Sciences, 17(2): 3-16.

HARASANI, W. I. (2013) "Evaluation and Selection of a Fleet of Aircraft Located in Madniah, Saudi Arabia" Editorial and Advisory Board, $4(2): 40$.

HU, J. and JIAN-LIANG, P. (2008) "Application of supplier selection based on the AHP theory" IEEE International Symposium, IEEE: 1095-1097.

ISHIZAKA, A. and NEMERY, P. (2013) "Multi-Criteria Decision Analysis Methods and Software" West Sussex, John Wiley \& Sons Inc. 
LISTES, O. and DEKKER, R. (2002) "A scenario aggregation based approach for determining a robust airline fleet composition" Econometric Institute Report El 2002-17, Erasmus University Rotterdam, The Netherlands.

LISTES, O. and DEKKER, R. (2005) "A scenario aggregationbased approach for determining a robust airline fleet composition for dynamic capacity allocation" Transportation Science, 39(3): 367-382.

KURUÜZÜM, A. and ATSAN, N. (2001) "Analitik Hiyerarşi Yöntemi ve İşletmecilik Alanındaki Uygulamaları" Akdeniz Üniversitesi İktisadi ve İdari Bilimleri Fakültesi, 1(1): 83-105.

ORGAN, A. and KATRANCI, A. (2016) "Kirllgan Sekizli Olarak Adlandırılan Ülkelerin Yaşanılabilirlik Düzeyinin Çok Kriterli Karar Verme Teknikleri İle Değerlendirilmesi" Balkan Sosyal Bilimler Dergisi, 16: 73-90.

ÖZDEMİR, Y., BAŞLIGİL, H. and KARACA, M. (2011) "Aircraft selection using analytic network process: a case for Turkish airlines" In Proceedings of the World Congress on Engineering (WCE): 9-13.

ÖZDEMİR, Y. and BAŞLIGILL, H. (2016) "Aircraft selection using fuzzy ANP and the generalized choquet integral method: The Turkish airlines case" Journal of Intelligent \& Fuzzy Systems, 31(1): 589-600.

ÖMÜRBEK, N. and ŞIMSŞEK, A. (2012) "Üniversite öğrencilerinin cep telefonu tercihlerinin Analitik Hiyerarşi Prosesi ile belirlenmesi" Niğde Üniversitesi İktisadi ve İdari Bilimler Fakültesi Dergisi, 5(1): 116-32.

ÖZDAĞOĞLU, A. (2013) "İmalat işletmeleri için eksantrik pres alternatiflerinin COPRAS yöntemi ile karşılaștırılması" Gümüşhane Üniversitesi Sosyal Bilimler Enstitüsü Dergisi, 4(8): 1-22.

ÖZDAĞOĞLU, A. (2014) "Normalizasyon Yöntemlerinin Çok Ölçütlü Karar Verme Sürecine Etkisi-MOORA Yöntemi İncelemesi" Ege Akademik Bakıș, 14(2): 283-294.

ÖZDEMIR, M. S. (2002) "Bir işletmede analitik hiyerarşi süreci kullanılarak performans değerleme sistemi tasarımı" Endüstri Mühendisliği Dergisi, 13(2): 2-11.

ÖZTÜRK, Ö. and ÇEKEROL, G. (2015) "Anadolu Üniversitesi Açıköğretim Fakültesi Bürosu Yeri Seçiminin Analitik Hiyerarşi Süreci İle Belirlenmesi" Dumlupınar Üniversitesi Sosyal Bilimler Dergisi (50): 148-161.

PODVEZKO, V. (2011) "The comparative analysis of MCDA methods SAW and COPRAS" Inzinerine Ekonomika-Engineering Economics, 22(2): 134-146. 
ROSKAM, J. (1990) "Aircraft design. Part VII Airplane cost estimate, Roskam Aviation and Engineering Corporation", Ottawa, Kansas, USA.

SAATY, T. L. (2008) "Decision making with the analytic hierarchy process" International Journal of Services Sciences, 1(1): 83-98.

SARIÇALI, G. and KUNDAKÇI, N. (2016) "AHP ve COPRAS yöntemleri ile otel alternatiflerinin değerlendirilmesi" International Review of Economics and Management, 4(1): 45-66.

SEE, T. K., GURNANI, A. and LEWIS, K. (2004) "Multi-attribute decision making using hypothetical equivalents and inequivalents" Journal of Mechanical Design, 126(6): 950-958.

SEE, T. K., and LEWIS, K. (2002) " Multiattribute decision making using hypothetical equivalents" In ASME 2002 International Design Engineering Technical Conferences and Computers and Information in Engineering Conference, 401-410.

SUPÇILLER, A. A. and ÇAPRAZ, O. (2011) "AHP-TOPSIS Yöntemine Dayali Tedarikçi Seçimi Uygulaması" İstanbul Üniversitesi İktisat Fakültesi Ekonometri ve İstatistik Dergisi (13): 1-22.

ŞIMSŞEK, A., ÇATIR, O. and ÖMÜRBEK, N. (2015) "TOPSIS ve MOORA Yöntemleri ile Tedarikçi Seçimi: Turizm Sektöründe Bir Uygulama" Balıkesir Üniversitesi Sosyal Bilimler Enstitüsü Dergisi, 18(33): 133-161.

TEPE, S. and GÖRENER, A. (2014) "Analitik Hiyerarşi Süreci Ve Moora Yöntemlerinin Personel Seçiminde Uygulanması" İstanbul Ticaret Üniversitesi Fen Bilimleri Dergisi, 13(25): 1-14.

TEOH, L. E. and KHOO, H. L. (2015) "Airline Strategic Fleet Planning Framework" Journal of the Eastern Asia Society for Transportation Studies, 11: 2258-2276.

VASIGH, B., FLEMING, K. and TACKER, T. (2012) "Foundations of Airline Finance: Methodology and Practice" Furnham, Ashgate Publishing Company.

WANG, T. C. and CHANG, T. H. (2007) "Application of TOPSIS in evaluating initial training aircraft under a fuzzy environment" Expert Systems with Applications, 33(4): 870-880.

WENSVEEN, J. G. (2011) "Air Transportation: A management perspective" 7th edition, Surrey, Ashgate.

ZHAO, J., XIONG, J., PENG, L., TU, H. abd LIU, J. (2009) "Research of Modeling the Evaluation Choice on Materials Suppliers Based on AHP. World Congree on Software Engineering, IEEE: 416-419. 
YEH, C. H. and CHANG, Y. H. (2009) "Modeling subjective evaluation for fuzzy group multicriteria decision making" European Journal of Operational Research, 194(2): 464-473. 